\title{
RESENHAS|REVIEWS
}

CARVALHO, Claudio; RODRIGUES, Raoni. O direito à cidade. Rio de Janeiro: Lumen Juris, 2016.. Capítulo 3 e 8, pp. 35-75.

\section{A Luta de Classes um Ponto de partida para se Compreender a Cidade CONTEMPORÂNEA}

THE CLASS STRUGGLE A STARTING POINT FOR UNDERSTANDING THE CONTEMPORARY CITY

\section{Juliani Cristina Lima Grochoski ${ }^{1}$}

Resumo: Trata-se da visão apresentada por Cláudio Carvalho e Raoni Rodrigues, a respeito do "Direito à Cidade". Inspirado no livro Henri Lefebvre filosofo e sociólogo francês, escritor do livro "Le droit à la ville", traduzido para o português como "Direito à Cidade", o livro trata de das forças convergentes dispostas dentro da cidade que competem para organizar seu traçado, guiar sua gestão especialmente em favor dos respectivos interesses. Trata também da distorção valorativa que a expressão, título do livro tem sofrido, sendo necessário um resgate do sentido real e aos valores fundantes do direto à cidade. Os autores também apontam para cooptação da classe política em favor dos interesses capitalistas, e a necessidade de uma recuperação da força popular, afim de garantir de fato, a gestão democrática da cidade.

Palavras-chave: Cidade. Urbanismo. Gestão democrática.

Abstract: This is the vision presented by Cláudio Carvalho and Raoni Rodrigues, regarding the "Right to the City". Inspired by the book Henri Lefebvre French philosopher and sociologist, writer of the book "Le droit à la ville", translated into Portuguese as "Right to the City", the book deals with the converging forces disposed within the city that compete to organize its layout, guide its management especially in favor of the respective interests. It also deals with the valuation distortion that the expression, title of the book has suffered, being necessary a rescue of the real meaning and the founding values of the right to the city. The authors also point to the cooptation of the political class in favor of capitalist interests, and the need for a recovery of popular strength, in order to guarantee in fact the democratic management of the city.

Keywords: City. Urbanism. Democratic management.

Durante muitos anos, as cidades se desenvolveram formando uma espécie de "tecido" de relações entre seus habitantes. Muitos serviços e produtos são demandados para o desenvolvimento e manutenção de uma cidade, isso tudo demanda organização. Essa organização acaba se centralizado no papel do Estado. (p. 35)

Hoje, o Estado também acaba sendo um mediador das forças existentes dentro do município.

1 Mestranda em Direito Negocial pela Universidade Estadual de Londrina (UEL). Graduada em direito pela Universidade Estadual de Maringá. Bolsista CAPES. 
Dentre essas forças existe a força do capital, empresas que visam estritamente o lucro e tentam manobrar a cidade segundo seus interesses, e que se opõe a massa de trabalhadores. (p. 36). Ou seja, o Estado precisa mediar o desenvolvimento, os direitos dos trabalhadores e dos demais moradores. Ocorre que, muitas vezes a classe política é cooptada pelos interesses capitalistas. (p.36)

"Enquanto as políticas públicas se tornam cada vez mais elitistas, a grande maioria dos bens de consumo coletivos é relegada a segundo plano, já que, comumente, eles não geram lucro privado: Daí nasce a crise urbana [..], da impossibilidade do sistema em produzir aqueles serviços cuja necessidade ele suscitou." Op. cit. (PACHUKANIS, São Paulo: E. V. Teoria marxista do direito. Tradução Sílvio Donizete Chagas, Acadêmica, 1988. p. 30). (p.36)

Para o autor "O caos e a degradação das nossas cidades não são decorrentes de um planejamento malfeito, mas sim representam uma vitória dos grupos que procuram extrair benefícios através da espoliação dos territórios urbanos." (p.37). Muitos desses grupos usam o "Direito à Cidade" como fundamento para legitimar seus interesses. Nesse sentido, é importante pensar "De que direito à cidade estamos tratando?"

O autor cita Porksen, autor alemão, que retrata como palavras da "moda" podem ter vários sentidos, sendo que, podem se encaixar em ideologias que não se referem ao sentido original da palavra, segundo o autor "O direito à cidade" é uma dessas expressões. (p.38)

Para o mesmo, devido a essa cooptação de direitos importantes são usados como cosméticos, campanhas ambientais e de desenvolvimento por exemplo. Contudo, pouco se sente de efetividade desses direitos na realidade cotidiana da cidade. (p.40)

Sendo que esse direito tem "adquirido matizes neoliberais" se fazendo necessário um resgate das características essenciais do Direito à Cidade. Que são: a universalidade, a indivisibilidade, a integralidade, a interdependência, a inalienabilidade e a progressividade.

"Universalidade: os benefícios do desenvolvimento urbano devem ser, distribuídos a todas as pessoas; indivisibilidade: o Direito à Cidade não pode ser fracionado, dividido; integralidade: todos os direitos ligados à dignificação da vida urbana são igualmente importantes, não devendo ser hierarquizados; interdependência: todos os direitos que decorrem do Direito à Cidade são extremamente coesos e a satisfação de um depende do cumprimento dê todos os outros; inalienáveis: é a qualidade de não poder ser perdido ou de não ser passível de qualquer tipo de negociação; Progressividade: refere-se aos esforços de tornar a cidade cada vez mais pertencente a todos os seus habitantes, através de uma radical democratização do acesso aos bens urbanos. A gestão urbana, baseada em um real Direito à Cidade, deverá se compromissar com a concretização e disseminação urgente dos direitos econômicos, sociais e culturais, revertendo o quadro de segregação socioespacial que marca a maioria das cidades". (p.41)

Também é essencial um retorno aos "princípios do direito à cidade", que devem orientar a criação e aplicação da lei, assim como a elaboração de políticas urbanas. Fundado em uma série de documentos históricos sobre o tema, o autor faz um resumo dos principais princípios que são: (p.

42)

1- Autodeterminação: os caminhos da cidade devem ser traçados democraticamente; 2-2-Igualdade, 
os benefícios devem ser divididos de maneira justa; 3-Participação: Democratização das dicções urbanas; 4- Não Discriminação; 5- Transparência na gestão; f) Corresponsabilidade dos atores da urbanização; 7- Atenção prioritária às pessoas em situação de vulnerabilidade social. (p. 42-44) Adiante, o autor retrata os desafios de uma nova política, que segundo o mesmo são três: $1^{\circ}$ Enfraquecimento político do cidadão moderno: Em grandes centros, devido à grande quantidade de pessoas, os laços de proximidade se tornam mais frágeis, e as pessoas mais individualistas. Sensação de impotência das próprias ações para mudar a realidade acaba reduzindo o interesse político. (p.58)As audiências públicas tem a intenção de melhorar essa interação política, contudo o que se nota é que cada pequeno grupo acaba defendendo seus próprios interesses. (p.60); $2^{\circ}$ Evolução urbana no Brasil: Um dos principais problemas apontados é a falta de um planejamento comum, que pode ser motivo de problemas já cristalizados, como a desigualdade social dentro das cidades. No Brasil as antigas ocupações, e cidades se deram praticamente sem planejamento, o que contribuiu para muitos dos problemas hoje vividos. (p.65); $3^{\circ} \mathrm{A}$ política na cidade global: A globalização e o capital, também influenciam em questões políticas e isso acaba também, por refletir na estrutura das cidades. (p.66-67)

Por fim, o autor ressalta o desejo de que o manifesto do direito a cidade seja mais que um estudo teórico, sendo colocado em pratica, fazendo com que valores como a inclusão democrática sejam seguido de fato. Ressalta também, o fato do capital ter superado até mesmo a própria política. Termina o livro com um dilema, como fica a situação das pessoas nessas cidades em que o planejamento é todo voltado ao capital, como a lógica política pode se sobressair a isso? 